\title{
PENGELOLAAN PROPERTI RUKOS BERBASIS PADA KINERJA ASET
}

\author{
Katharina Priyatiningsiha ${ }^{\mathrm{a}}$, Iwan Mulyawan ${ }^{\mathrm{b}}$, dan Rosma Pakpahan ${ }^{\mathrm{c}}$ \\ aProgram Studi Manajemen Aset, ${ }^{b}$ Program Studi Manajemen Pemasaran-Jurusan Administrasi Niaga , c \\ Program Studi Keuangan dan Perbankan -Jurusan Akuntansi - Politeknik Negeri Bandung
}

\begin{abstract}
ABSTRAK
Usaha membuka Rukos (Rukos) seperti bisnis pada umumnya yaitu untuk mendapatkan penghasilan dan keuntungan bagi pemiliknya. Kondisi usaha bisnis Rukos di seputar kawasan kampus merupakan bisnis yang menjanjikan, bersifat jangka panjang dengan persaingan yang berfokus pada pelayanan. Pemilik Rukos belum sepenuhnya menjalankan usaha tersebut secara profesional, hal ini diindikasikan melalui tingkat hunian yang belum optimal. Kinerja aset properti Rukos dapat dinilai kinerjanya melalui empat ukuran yaitu kondisi fisik, fungsional, utilitas dan keuangannya. Kegiatan pengabdian kepada masyarakat ini dilakukan di daerah kawasan kampus Politeknik Negeri Bandung yaitu daerah Ciwaruga dan daerah Sarijadi. Responden penelitian ini adalah pemilik atau pengelola Rukos dengan jumlah responden 20 usaha Rukos. Teknik pengumpulan data dengan kuesioner, wawancara dan observasi. Data kegiatan ini menunjukan kinerja aset properti Rukos secara umum perlu ditingkatkan. Sehubungan dengan hasil tersebut maka kegiatan ini dilanjutkan dengan memberi pemahaman kepada pengelola atau pemilik usaha Rukos untuk mengelola dengan manajemen yang diberikan melalui pelatihan. Hasil pelatihan ini diharapkan dapat membuka pemahaman baru tenang pengelolaan Rukos sebagai aset properti dan merupakan bisnis yang strategis sehingga bukan hanya mendapatkan penghasilan dan keuntungan tetapi jangka panjangnya memiliki nilai aset yang makin meningkat.
\end{abstract}

Kata kunci: properti, rukos, kinerja aset

\section{PENDAHULUAN}

Kenaikan penduduk dalam satu dekade di Kabupaten Bandung Barat sebesar 21,3\% per tahun dan di kota Bandung sebesar $12 \%$, hal ini menyebabkan peningkatan permintaan kebutuhan rumah tinggal, baik secara permanen maupun sementara karena sifat pekerjaan atau kegiatan yang dilakukan penduduk di Jawa Barat. Berdasarkan kontribusi sektor ekonomi terhadap
PDRB Kabupaten Bandung Barat per periodik 2 tahunan terhadap sektor jasa-jasa termasuk sewa rukos memberi kontribusi sebesar 5,17 \% ( Jawa Barat dalam Angka - BPS,2015). Rukos (Rukos) merupakan perumahan yang terdapat di Kabupaten Bandung Barat yang disediakan oleh pengembang/developer atau yang didirikan sendiri oleh masyarakat. Secara umum Kabupaten Bandung Barat dalam satu tahun dapat memiliki 
jumlah rumah yang didirikan oleh masyarakat sejumlah 284.180 unit, meski demikian jumlah ini belum mampu mencukupi/memenuhi kebutuhan penduduk dan masih diperlukan penambahan, hal ini juga dikarenakan kenaikan jumlah urbanisasi dan migrasi sehingga dapat dipenuhi dengan rumah sewa atau rukos. Rukos adalah salah satu tempat tinggal yang terdiri dari kamar-kamar yang dihuni untuk tinggal sementara atau di sewa oleh seseorang. Usaha atau bisnis rukos dapat dimasukan dalam produk jasa dengan menawarkan sebuah kamar atau tempat untuk ditinggali dengan sejumlah pembayaran tertentu pada setiap periode tertentu. Bentuk fisik rukos terdiri dari beberapa kamar dengan ukuran normal $3 \times 4$ meter persegi, umumnya disewa oleh individu yang membutuhkan tempat tinggal sementara. Mahasiswa adalah golongan generasi muda yang menuntut ilmu di perguruan tinggi, sebagian besar dari mahasiswa adalah pendatang atau berasal dari daerah lain yang membutuhkan rukos untuk solusi tempat tinggal selama mereka menempuh pendidikan di perguruan tinggi. Tujuan utama mahasiswa menempuh pendidikan adalah untuk proses pembelajaran, dan memerlukan tempat tinggal atau kamar kos yang letaknya berdekatan dengan kampus sehingga permintaan dekat dengan kampus ini membuat sebagian besar rukos tersebut berupaya menyediakan banyak ruangan atau kamar, kondisi 'crowded' ini menimbulkan mahasiswa yang tinggal di dalamnya merasa terganggu dengan keadaan dalam rukos dan berpengaruh terhadap konsentrasi belajar, tingkat stress, prestasi belajar dan motivasi belajar mahasiswa tersebut.

Kawasan rukos yang berlokasi dan dinilai strategis apabila berdekatan dengan satu atau lebih kampus. Padatnya kawasan tersebut memberikan efek density pada masyarakat asli ataupun mahasiswa yang menyewa rukos tersebut. Mahasiswa yang tinggal di kawasan padat dan rukos dengan banyak penghuni dalam bentuk bangunan yang sempit, kamar yang berderet, suara berisik yang ditimbulkan oleh penghuni lain dapat disebabkan karena kekurangan space. Goffman (dalam Altman, 1975) menyebutkan space adalah ruang disekeliling seseorang dengan batas - batas yang tidak jelas dimana seseorang tidak boleh memasuki. Masih menurut Goffman kondisi ini menggambarkan ruang personal sebagai jarak atau daerah di sekitar individu dimana jika dimasuki orang lain, menyebabkan ia akan merasa batasnya dilanggar, merasakan kurang nyaman sehingga menjadikan personal (mahasiswa) merasa kekurangan ruang gerak hingga dapat meminimalisir kegiatan dan menjadikan mahasiswa mempunyai kebiasaan buruk bermalas-malasan di kamar rukos yang berpengaruh pada motivasi belajarnya.

Faktor paling dominan yang menentukan keputusan mahasiswa dalam memilih rukos yaitu faktor lingkungan, selain faktor-faktor harga sewa, fasilitas, referensi, lokasi, keamanan, dan pelayanan (Hajar, dkk, 2012). Menurut Hills dan Levy, ada keterkaitan antara lingkungan tempat bekerja atau belajar yang moderen dengan banyak interaksi antara ruang, 
DIFUSI

Volume1, No.1 Januari 2018

karakteristik fisik dan pengguna (Hills and Levy, 2014). Jika pengelolaan rukos ini kurang memperhatikan kebutuhan mahasiswa maka yang terjadi adalah tidak direkomendasikannya rukos dan tidak menjadikan pilihan bagi calon penyewa/mahasiswa. Sehingga pengelolaan aset rukos sebagai bisnis atau usaha tidak semata bertujuan mendapatkan keuntungan jangka pendek yaitu menghasilkan pendapatan tetapi lebih daripada itu mengelola aset rukos sebagai aset properti dengan tujuan investasi jangka panjang.

Pengelolaan aset memerlukan tahapan yang dimulai degan mengetahui perencanaan kebutuhan, pengadaan, inventarisasi, penilaian, operasi dan pemeliharaan, optimasi, sampai penghapusan. Pentig bagi pengelola rukos untuk yujuan jangka panjang melalukan tahapan pengelolaan aset, terutama jika aset sudah dioperasikan maka perlu dilakukan penilaian dari kinerja aset tersebut. Melalui evaluasi kinerja aset berdasar fisik, keuangan dan utilitas/pemasarannya dapat dibuat suatu pola pengelolaan aset properti yang strategis.

Salah satu tujuan dilakukannya kegiatan pengabdian kepada masyarakat adalah untuk melakukan transfer pengetahuan secara praktis melalui suatu survei lapangan untuk mengetahui kondisi objek yaitu usaha rumah kos disekitar kampus, untuk kemudian dilakukan evaluasi dari kinerja aset berdasar fisik, keuangan dan utilitas/pemasarannya. Selanjutnya pengelola atau pemilik rukos diberi pemahaman tentang pengelolaan aset pada bisnis usaha rukos sebagai aset properti.
Kegiatan ini dilakukan melalui observasi, wawancara dan pelatihan tentang pengelolaan aset properti rukos yang berfokus pada kinerja fisik, keuangan dan pemasaran.

Pengabdian kepada Masyarakat ini diharapkan dapat memberikan manfaat bagi pihak masyarakat pemilik rukos dengan suatu pemahaman dari konsep keilmuan manajemen aset, keuangan dan pemasaran memiliki nilai profesional yang strategis. Bagi institusi hasil pengabdian kepada masyarakat dengan kegiatan survei dan pelatihan diharapkan dapat menyumbang pikiran bagi kemajuan tridharma perguruan tinggi, yang pada gilirannya dapat meningkatkan kompetensi sebagai institusi yang memiliki keunggulan dalam manajemen aset khususnya untuk aset properti.

\section{METODE}

Kegiatan survei dilakukan melalui studi literatur pengelolaan aset properti dan studi landasan normatif aset properti di Indonesia untuk mendapatkan gambaran bagaimana kondisi aset properti Rukos dan pengelolaannya.

Evaluasi dari kinerja aset Rukos berdasar fisik, keuangan dan utilitas/pemasarannya

Properti termasuk Rukos menunjukkan kepada sesuatu yang biasanya dikenal sebagai entitas dalam kaitannya dengan kepemilikan seseorang atau sekelompok orang atas suatu hak eksklusif. Bentuk utama dari aset properti ini adalah termasuk tanah, personal property atau kepemilikan barang secara fisik 
lainnya serta kekayaan intelektual. Hak atas kepemilikian ini terkait dengan properti yang menjadikan sesuatu barang menjadi "kepunyaan seseorang" baik pribadi maupun kelompok, menjamin si pemilik atas haknya untuk melakukan segala suatu terhadap properti sesuai dengan kehendaknya, baik untuk menggunakannya ataupun tidak menggunakannya, atau untuk mengalihkan hak kepemilikannya. Beberapa ahli filosofi menyatakan bahwa "Properti pribadi" kadang digunakan sebagai sesuatu istilah yang maknanya mirip dengan " kepemilikan individu", tetapi istilah tersebut juga dapat digunakan untuk suatu kepemilikan properti secara kolektif dalam bentuk " "kepemilikan perusahaan". Suatu perencanaan yang matang dan menyeluruh dalam suatu proses manajemen, termasuk pengelolaan properti rukos sangat dibutuhkan, untuk itu perlu diketahui lebih dulu definisi dari manajemen properti. Definisi praktis manajemen properti yang diberikan oleh Department of Business and Industry Real Estate Division, dikatakan bahwa : Property Management means the physical, administrative or financial maintenance and management of real property, or the supervision of such activities for a fee, commission or other compensation or valuable consideration, pursuant to a property management agreement. (Department of Business and Industry - Real Estate Divisionwww.red.state.nv.us, 2008)

Berdasar definisi dari Real Estate Handbook, properti is the rights that one individual has in lands or goods to the exclusion of all other; rights gained from the ownership of wealth. (Jack C. Harris et.all, 1987 dalam Hariyono, 2003). Jadi suatu properti termasuk rukos adalah hak yang dimiliki seseorang atas tanah dan kekayaan dalam suatu kepemilikan dengan melakukan pemeliharaan fisik, administratif atau keuangan dan manajemen real properti, atau pengawasan kegiatan seperti untuk biaya, komisi atau kompensasi lain atau pertimbangan berharga, sesuai dengan perjanjian.

Douglas Street (dalam Hariyono, 2003) menyatakan, manajemen properti bertujuan untuk mengawasi properti yang terkait dengan kepemilikan serta melaksanakan aktivitas sewa menyewa, negoisasi harga sewa, menilai kembali harga sewa, meneliti pemeliharaan secara fisik, melakukan upgrading atau merger, sensitif terhadap peluang pengembangan, dan secara hukum mewakili pemilik dan memenuhi kewajiban sosial terhadap masyarakat.

Kinerja operasi dari properti sebagai suatu bisnis mengikuti tugas-tugas yang diinginkan oleh pemilik properti, seperti : akuntansi, pelaporan, pengarahan, pemeliharaan dan perawatan, pembayaran pajak, provisi utilitas dan asuransi, remodeling, penetapan tarif dan pengumpulan, pengembangan, pengadaan dan dispoisisi, rehabilitasi, kelayakan, keuangan, akuntansi pajak pendapatan.

Kinerja Aset properti : Kondisi aset properti yang menggambarkan kemampuan suatu aset dalam 
DIFUSI

Volume1, No.1 Januari 2018

memberikan suatu pelayanan sesuai dengan harapan yang diukur dari kondisi fisik, fungsionalitas, tingkat utilisasi, kinerja keuangan

Empat pengukuran pelayanan dari kinerja aset properti Rukos ini sebagai sub-variabel atau dimensi dapat dijelaskan sebagai berikut :

Kondisi Fisik : Suatu aset rukos sebagai properti perlu dipelihara agar berada dalam kondisi yang memadai secara fisik untuk digunakan sesuai dengan tujuan yang telah ditetapkan dan memenuhi standar kesehatan dan keamanan yang relevan. Dimensi kondisi fisik ini dapat diukur dari beberapa indikator yaitu luas lahan, luas bangunan, luas per kamar tidur, dibangun pada tahun berapa, luas ruang lain (parkir, dapur, kamar mandi, ruang tamu/makan), kondisi fisik bangunan secara keseluruhan, kondisi fisik bangunan per kamar/ruangan, kondisi higenitas kebersihan, kondisi higenitas sirkulasi udara (tidak lembab/pengap) dan kondisi keamanan.

Fungsionalitas : Ukuran tingkat kecocokan aset rukos sebagai properti tersebut difungsikan terkait dengan indikator yang diukur fasilitas per kamar, keleluasan (density), ketersediaan dan ukuran tempat tidur, ketersediaan dan ukuran lemari pakaian, ketersediaan dan ukuran meja belajar, ketersediaan dan ukuran wifi serta ketersediaan dan ukuran daya listrik.

Utilisasi : Ukuran seberapa intensif suatu asset digunakan untuk memenuhi tujuan pemberian pelayanan, sehubungan dengan potensi kapasitas aset. Indikator dari utilisasi ini diukur melalui ketersediaan kamar dengan jumlah penghuni per kamar, ketersediaan dan ukuran fasilitas tambahan (parkir mobil, daya listrik), ketersediaan penambahan ekstra bed, kersediaan air minum, dan ketersediaan fasilitas makan/catering.

Keuangan :Pengukuran kinerja untuk mengetahui apakah aset tersebut dapat memberikan pelayanan yang aktif secara ekonomis atau tidak, dan diukur serta dinilai berdasarkan tiga indikator utama yaitu biaya operasional, biaya pemeliharaan, dan net return on asset value. Indikator dari keuangan ini diukur melalui harga sewa, sistem pembayaran, biaya perawatan/pemeliharaan, permodalan, biaya hutang, biaya penyusutan, mulai dan tempo hutang.

Setelah diperoleh gambaran dari operasionalisasi variabel tentang apa yang harus diamati pada objek pengabdian maka yang berikut dilakukan observasi lapangan dan interview.

Memberi pemahaman tentang pengelolaan aset pada bisnis usaha rukos sebagai aset properti

Setelah target pertama tercapai maka target kedua selanjutnya adalah dengan memberikan sosialisasi melalui pelatihan singkat tentang Pemaparan Hasil Evaluasi Kinerja Rukos, Pengelolaan Rukos sebagai Properti, Pengelolaan Keuangan Rukos , dan Pengelolaan Pemasaran Rukos 
DIFUSI

Volume1, No.1 Januari 2018

Pemahaman melalui observasi dan interview pada 2 mitra pemilik rukos di sebagai responden dan role model untuk menganalisis identifikasi permasalahan yang diajukan menggunakan metode deskriptif dengan objek penelitian melalui pengumpulan data inventarisasi, legal aspek, serta melihat langsung objek fisik untuk dievaluasi. Setelah dilakukan evaluasi objek rukos maka selanjutnya dianalisis dengan konsep dan normatif pengelolaan aset properti sampai dihasilkan laporan kemajuan. Responden yang terlibat dalam pengelolaan aset dan konsumen/pengguna aset properti rukos, sedangkan cara dan instrumen pengumpulan data melalui studi literatur untuk data sekunder, observasi serta interview, angket dan survey untuk data primer.

Keseluruhan proses data dan analisis menggunakan pendekatan intrepretasi secara kualitatif dan kuantitatif. Rancangan kegiatan disusun dengan mengidentifikasi permasalahan dalam lapangan dan diselesaikan melalui pendekatan manajemen properti artinya secara keseluruhan tujuan pengabdian ini akan terjawab dengan mempelajari, memahami, mengamati, dan menyimpulkan pengeloaan rukos yang dilakukan oleh pemilik dan akan ditingkatkan menjadi pengeloaan berdasar manajemen properti.

\section{HASIL DAN PEMBAHASAN}

\subsection{Hasil}

Mengacu pada identifikasikan permasalahan dari kegiatan ini yaitu maka hasil yang dapat ditunjukan dengan dilaksanakan suatu evaluasi dari kinerja aset berdasar fisik, keuangan dan utilitas/pemasarannya, serta memberikan pemahaman tentang pengelolaan rukos sebagai aset properti melalui kegiatan pelatihan.

Berdasar konsep penilaian kinerja aset rukos dilakukan survei melalui kuisioner dan observasi di lapangan maka diperoleh hasil sebagai berikut:

1. Kondisi Fisik :

Secara fisik dapat diuraikan sebagai berikut :

a. Rata-rata luas lahan $284 \mathrm{~m} 2$ dan luas bangunan $278 \mathrm{~m} 2$, jadi dapat dikatakan rata-rata bangunan Rukos memiliki lebih dari 1 lantai

b. Luas kamar tidur paling kecil berukuran 2,5 x 2,5 $\mathrm{m} 2$, sedangkan yang lebih luas berukuran $3 \times 4 \mathrm{~m} 2$

c. Usia fisik bangunan yang terbaru 1 dan yang terlama 21 tahun

d. Rata-rata Rukos memiliki ruang lain , seperti tempat parkir, dapur, dan kamar mandi, ruang tamu, dan hanya 1 Rukos yang menyediakan ruang makan. Secara keseluruhan luas ruang lain ini seluas sekitar $4,5 \mathrm{~m} 2$ sampai dengan $80 \mathrm{~m} 2$

e. Persepsi pengelola untuk kondisi fisik bangunan secara keseluruhan memiliki nilai 3,26 dari skla 1 sd 5. Jadi dapat dikategorikan baik

f. Persepsi pengelola untuk kondisi fisik bangunan per kamar/ruangan memiliki nilai 3,18 dari skla 1 sd 5. Jadi dapat dikategorikan baik

g. Persepsi pengelola untuk kondisi higenitas kebersihan memiliki 
nilai 2,72 dari skla 1 sd 5. Jadi dapat dikategorikan kurang baik

h. kondisi higenitas sirkulasi udara (tidak lembab/pengap) memiliki nilai 2,66 dari skla 1 sd 5. Jadi dapat dikategorikan kurang baik

i. kondisi keamanan memiliki nilai 2,73 dari skla 1 sd 5. Jadi dapat dikategorikan kurang baik

2. Fungsionalitas :

Tingkat kesesuaian fungsi sebagai rukos, dengan hasil rata-rata. Secara fungsional dapat diuraikan sebagai berikut :

a. Rata-rata luas Fasilitas yang tersedia per kamar adalah tempat tidur (baik), kasur, bantal (kurang baik), meja dan kursi belajar (kurang baik), lemari pakaian (kurang baik), dan lemari/rak buku (tidak baik)

b. Keleluasan (density) ( penataan fasilitas per kamar (kurang baik)

c. Kesesuaian dan ukuran tempat tidur (kurang baik)

d. Kesesuaian dan ukuran meja belajar (kurang baik)

e. Ketersediaan dan ukuran wifi (kurang baik)

f. Kesesuaian dan ukuran daya listrik (baik)

\section{Utilisasi :}

Pemenuhan layanan yang diberikan rukos, memberi ukuran dengan

Secara utilitas dapat diuraikan sebagai

berikut :

a. Rata-rata ketersediaan kamar dengan jumlah penghuni per kamar baik

b. Ketersediaan dan fasilitas tambahan yang terdiri dari parkir mobil (tidak baik), parkir motor (kurang baik), penambahan daya listrik (kurang baik), dan laundry (sangat tidak baik)

c. Ketersediaan penambahan ekstra bed (tidak baik)

d. Ketersediaan air minum (tidak baik)

e. Ketersediaan makan/makanan/catering (sangat tidak baik)

4. Keuangan:

Besaran biaya, harga, modal dan waktu penggunaan kinerja keuangan Secara keuangan dapat diuraikan sebagai berikut :

a. Rata-rata harga sewa kamar per bulan antara 250.000 sampai 350 ribu rupiah

b. Sistem pembayaran yang terbaik adalah per tahun $(52,94 \%)$

c. Biaya perawatan/pemeliharaan yang waktunya tidak tertentu lebih besar prosentasenya yaitu $41,17 \%$

d. Besar biaya peme;iharaan dan biaya penyusutan tidak diisi, artinya tidak ada yang menyediakan biaya pemeliharaan dan biaya penyusutan

e. Permodalan baik asal sumber modal dan prosentasenya tidak terdata, artinya tidak ada yang merencanakan masalah permodalan dari bisnis Rukos ini termasuk bunga, jangka waktu pinjam dan waktu peminjaman

Hasil evaluasi kinerja pada pembahasan diatas selanjutnya dianalisis untuk diolah dan dipersiapkan juga materi sosialisasi 
DIFUSI

Volume1, No.1 Januari 2018

yang diberikan kepada mitra peserta pemilik Rukos melalui pelatihan singkat tentang pemaparan hasil evaluasi kinerja Rukos, dan pemaparan materi.

\subsection{Pembahasan}

Pengelolaan aset properti atau manajemen aset properti adalah istilah tertentu dari manajemen aset yang berfokus pada aset fisik, bukan hanya keuangan. Manajemen properti dibutuhkan dengan tujuan untuk mendapatkan tingkat layanan properti yang dibutuhkan masyarakat melalui cara yang efisien dalam pengelolaan asetnya, mulai dari perencanaan kebutuhan, pengadaan, operasional, pemeliharaan, sampai penghapusan.

Hasil dari kinerja fisik yang terukur dari luas kamar tidur sesuai dengan ukuran keluasan minimal sebuah kamar tidur. Ukuran untuk usia fisik bangunan mencukupi (< 30tahun) dengan penambahan ruang lain, seperti tempat parkir, dapur, dan kamar mandi, ruang tamu, dan ruang makan yang keluasan memadai namun jumlahnya terbatas. Persepsi pengelola untuk kondisi fisik bangunan secara keseluruhan memiliki nilai baik, demikian pula pada kondisi fisik bangunan per kamar/ruangan memiliki nilai baik. Nilai yang dinilai kurang baik adalah pada kondisi higenitas kebersihan, kondisi higenitas sirkulasi udara (tidak lembab/pengap) dan kondisi keamanan.

Hasil evaluasi secara fungsional memiliki nilai baik hanya pada luas fasilitas tempat tidur yang tersedia per kamar, sedangkan nilai kurang baik pada fasilitas kasur dan bantal, meja dan kursi belajar, lemari pakaian, dan lemari/rak buku. Demikian pula nilai keleluasan (density) / penataan fasilitas per kamar, kesesuaian dan ukuran tempat tidur, kesesuaian dan ukuran meja belajar, dan ketersediaan dan ukuran wifi nilainya tidak baik.

Hasil evaluasi kinerja utilitas menunjukan nilai baik hanya pada ketersediaan kamar dengan jumlah penghuni per kamar, sedangkan ketersediaan fasilitas tambahan seperti parkir motor dan penambahan daya listrik memiliki nilai kurang baik, dan parkir mobil, penambahan ekstra bed, ketersediaan air minum dan memiliki nilai tidak baik, bahkan laundrydan katering makanan memiliki nilai sangat tidak baik.

Hasil kinerja keuangan masih perlu dilakukan pemahaman karena penetapan rata-rata harga sewa kamar per bulan antara 250.000 sampai 350 ribu rupiah yang dilakukan dengan sistem pembayaran per tahun hanya dilakukan sebagian pemilik Rukos yaitu 52,94\%. Sedangkan biaya perawatan/pemeliharaan yang waktunya tidak tertentu lebih banyak dilakukan yaitu $41,17 \%$ dari pemilik Rukos tanpa menghitung besarannya. Sedangkan permodalan baik asal sumber modal dan prosentasenya tidak ada yang merencanakan masalah permodalan dari bisnis Rukos ini termasuk bunga, jangka waktu pinjam dan waktu peminjaman.

Penyediaan properti merupakan tanggung jawab dan peran pemilik sebagai pemegang kunci kebijakan karena pada dasarnya properti adalah 
aset yang dibangun untuk melakukan layanan kepada masyarakat. Tantangan dalam pelayanan aset properti rukos adalah bagaimana mewujudkan rukos yang sesuai kebutuhan konsumen (mahasiswa) dan sesuai dengan keterbatasan sumberdaya (SDM, dana, dan organisasi) sehingga mampu memberikan manfaat pelayanan transportasi yang memadai dan sinergis serta meningkatkan aksesibilitas dan mobilitas dari barang dan jasa sehingga dapat meningkatkan daya saing nasional.

Keterlibatan masyarakat dan pihak swasta sebagai stakeholders dapat mengarahkan kualitas properti jalan sesuai kepentingan stakeholders, seperti dijelaskan oleh Humplick dan Peterson dalam Karlaftis dan Kepaptsoglou (2012). Kepentingan stakeholders dalam sektor properti memiliki kontradiksi antara ketertarikan dan harapan sehingga mengakibatkan penilaian dan pengukuran dimensi kinerja bervariasi.

Fuzi (2012) menyatakan ada dua tujuan manajemen properti sesuai sasarannya, yaitu (1) tujuan jangka pendek adalah tujuan operasional yang harus dicapai dalam kegiatan operasional sehari-hari, seperti pembuangan sampah, penataan dan kebersihan ruangan aset properti atau penataan dan kebersihan kebun/taman; memperbaiki pipa atau pekerjaan harian yang teknis yang kemungkinan harus dikerjakan oleh orang yang berpengalaman; memastikan bahwa segala sesuatu di lokasi sudah baik sesuai dengan standar kualitas dari properti itu sendiri, dan (2) tujuan jangka panjang adalah tujuan strategis yang merupakan perumusan kebijakan dan penjelasannya, perumusan program, penerapan dan aktivitas program, yang lebih bertujuan untuk mencari hasil terutama bagi pemilik properti. Contoh, tujuan dari seorang pemilik Rukos untuk memperbaiki Rukosnya dari dua lantai menjadi lima lantai dalam kurun waktu lima tahun bagi seorang pemilik /manajer properti berarti harus memastikan dan memonitor seluruh pekerjaan pokok diarahkan untuk pencapaian tujuan dalam kurun waktu yang telah ditetapkan.

Dua tujuan inilah yang diharapkan dapat dicapai oleh pengelola properti aset rukos sehingga diperoleh profitabilitas usaha dalam bentuk finance profit dan benefit. Finance profit merupakan keuntungan usaha sebagai modal untuk investasi dan benefit adalah nama baik pengelola properti yang keduanya merupakan tujuan jangka panjang dalam menunjang eksistensi usaha.

Penjelasan diatas merupakan alasan dilakukan pemahaman tentang bagaimana pengelolaan Rukos sebagai aset properti melalui kegiatan pelatihan.

Jadi dalam mengelola aset properti perlu diberi pedoman atau arahan bagi pengelola rukos tentang bagaimana mengoptimalkan dan melaksanakan keputusan pada pengadaan, operasi, pemeliharaan, pengawasan, pembaruan, peningkatan dan penghapusan aset dengan tujuan untuk memaksimalkan penyelenggaraan layanan, pengelolaan risiko dan meminimalkan biaya untuk memberikan prasarana yang aman dan ekonomis sehingga dapat mempengaruhi kinerja operasional dan 
DIFUSI

Volume1, No.1 Januari 2018

profitabilitas pemilik aset properti. Sesuai dengan hasil evaluasi kinerja dan tujuan pengelolaan aset properti Rukos ini maka dilaksanakan sosialisasi melalui pelatihan.

Luaran dari kegiatan ini adalah suatu permodelan pengelolaan aset rukos sebagai aset properti berdasar kinerja fisik, fungsi, utilitas, dan keuangan yang merupakan hasil pemetaan bagaimana pengelolaan aset properti Rukos dengan pemahaman manajemen aset properti , pemasaran dan keuangan dan temuan dari hasil evaluasi tersebut. Permodelan ini nantinya harus diuji dan disempurnakan melalui suatu penelitian yang lebih mendalam.

Permodelan ini mengacu pada kerangka pemikiran dari strategi pengelolaan aset yang dimulai dari mengetahui misi usaha / pemilik dan permintaan konsumen penyewa untuk kemudian dibuat perencanaan manajemen melalui rencana-rencana terkecil dan strategi pelayanan dari sumber daya yang tersedia dan dibutuhkan. Perencanaan manajemen sebagai perencanaan usaha /business plan harus disusun menjadi perencanaan yang strategis, yaitu perencanaan jangka panjang yang merupakan keputusan dan tindakan dari fisik bangunan sebagai aset properti yang berupa rencana strategis dari pengelolaan rukos, rencana SDM, rencana penggunaan teknologi informasi, dan rencana keuangan sebagai representasi dari kinerja aset properti Rukos sebagai rencana yang strategis. Rencana ini adalah bagian dari keputusan dan tindakan jangka panjang dalam pengadaan aset, operasi dan pemeliharaan aset, serta penghapusan/disposal aset, dan pada akhirnya dilakukan dalam penyampaian pelayanan Rukos dengan konsep pengelolaan aset properti yang stratejik dari Department of Treasury and Finance Tasmania , 2004

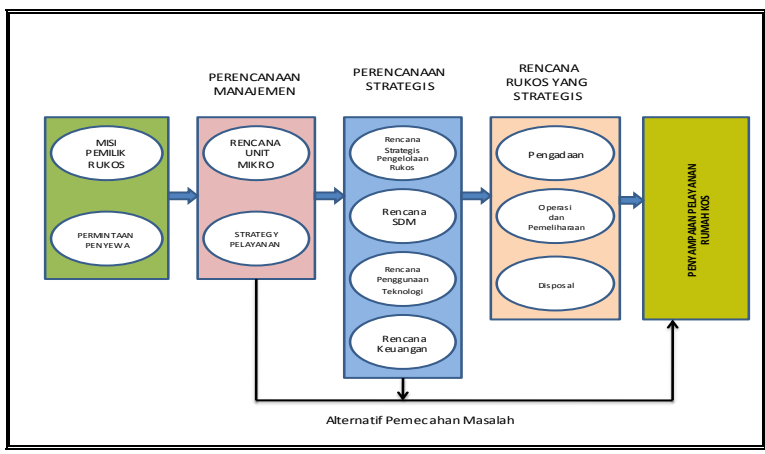

(Sumber: Peneliti, 2016)

\section{Gambar 1. Permodelan sebagai Luaran Kegiatan}

\section{SIMPULAN DAN SARAN}

Simpulan yang dapat disajikan adalah : 1). Kinerja Fisik dari sisi keluasan, usia teknis bangunan dan ruang tambahan dinilai baik, meskipun tetap perlu ditingkatkan karena nilai pada kondisi higenitas kebersihan, kondisi higenitas sirkulasi udara (tidak lembab/pengap) dan kondisi keamanan tidak baik. Perlu upaya pembenahan dengan lebih dahulu memberi pemahaman tentang pengelolaa aset properti melalui pelatihan.

2). Kinerja fungsional dinilai masih banyak kekurangannya terutama pada fasilitas kasur dan bantal, meja dan kursi belajar, lemari pakaian, dan lemari/rak buku, keleluasan (density) / penataan fasilitas per kamar, kesesuaian dan ukuran tempat tidur, kesesuaian dan ukuran meja belajar, dan ketersediaan dan ukuran wifi nilainya tidak baik. 
DIFUSI

Volume1, No.1 Januari 2018

Nilai baik hanya pada luas fasilitas tempat tidur yang tersedia per kamar. Penataan fungsi ini juga menyangkut bagaimana mengelola aset Rukos secara efisien dan efektif, dan pemahaman melalui pelatihan juga memberikan pengetahuan tentang keuangan dalam mengelola UMKM termasuk usaha Rukos.

3) Kinerja utilitas secara keseluruhan juga dinilai kurang yaitu terkait ketersediaan parkir mobil, parkir motor, penambahan daya listrik penambahan ekstra bed, ketersediaan air minum, laundry dan katering makanan. Nilai baik hanya pada ketersediaan kamar dengan jumlah penghuni per kamar. Kinerja utilitas perlu ditingkatkan dengan memberi pemahaman bagaimana Rukos disewakan selain sebagai kamar juga menyangkut ketersediaan dan kecukupan fasilitas pendukung sehingga konsumen akan terpenuhi kebutuhannya. Jadi pemahaman ini diisi dengan pengetahuan tentang pemasaran jasa dengan memahami pengelolaan aset properti Rukos.

4) Kinerja keuangan dinilai masih kurang baik untuk itu perlu dilakukan pemahaman pengelolaan aset properti dari sisi keuangan dengan memberi pemahaman terhadap penetapan harga terkait dengan biaya-biaya dan investasi. Investasi dari kinerja keuangan masih belum terdeteksi karena belum ada pengelolaan keuangan yang terkait dengan permodalan, sementara tujuan jangka panjang usaha properti sangat penting untuk keberlangsungannya.
Dari simpulan diatas dapat diberikan beberapa saran, yaitu bahwa kegiatan ini perlu melibatkan perbaikan kondisi fisik bangunan yang melibatkan kompetensi dari Jurusan Teknik Sipil , dan perlu dilakukan workshop untuk memberi pengetahuan investasi dan keuangan dalam rangka pengelolaan Rukos sebagai aset properti yang lebih profesional dalam wawasan bisnisnya.

\section{DAFTAR PUSTAKA}

A. Buku

[1] Hariyono, Arik. 2007. Manajemen Properti Tinjauan tentang Real Properti. Jakarta: Departemen Keuangan Republik Indonesia Badan Pendidikan dan Pelatihan Keuangan Umum.

[2] Schiffman, Leon G, dan Leslie Lazar Kanuk .1994. Consumer Behaviour. Sixth Edition, United State of America : Prentice Hall International. Inc.

B. Artikel Jurnal

[3] Hajar, Sitti. , Made Susilawati, Nilakusmawati. 2012. FaktorFaktor yang Mempengaruhi Keputusan Mahasiswa dalam Memilih Rumah Kost. e-Jurnal Matematika. Vol. 1 No. 1 Agustus 2012, 25-31

[4] Houten, van T.P. and Linda L. Zhang. .2010. Managing Assets in The Infrastructure Sector.International Journal of Engineering Business 
Management, Vol. 2, No. 2 pp. 55-60

[5] Hills, Raewyn and Deborah Levy Workspace design and fit-out: what knowledge workers value, , Property Management Vol. 32 No. 5, 2014, pp. 415-432

[5] Sudarmadi, Thamrin, Sabran Achyar. 2013. Implementasi Penertiban Rumah Kost Di Kecamatan Sungai Raya Kabupaten Kubu Raya. Jurnal Tesis PMIS-UNTAN-PSIAN2013

C. Sumber Rujukan dari Website

[6] Methven, Philip. 2011-12. Strategic Asset Management Framework. Project Manager SAMF Upgrade Project Infrastructure Policy and Planning

Department of Treasury and Finance. Diakses 15 Oktober 2016

[7] Prescott , Rasa Remenyte dan John Andrews . 2011. Review of Infrastructure Asset Management Methods for Networked Systems. United Kingdom :Nottingham Transportation Engineering Centre, University of Nottingham, UK (www. nottingham.ac.uk). Diakses tanggal 4 September 2016.

[7] APCC . 2001. Asset Management Public document of the Australian Procurement and Construction Council Inc. (APCC). P.O Box 106 DEAKIN WEST. ACT 2600. 6/42 Geils Court DEAKIN, ACT 2600. Diakses 15 Oktober 2015

[8] of Business and Industry - Real Estate Divisionwww.red.state.nv.us, Diakses 9 September 2016.

[9] Indonesia Hingga 2014 kritis . Jakarta : Metrotvnews.com . Nasional / Kamis, 24 November 2011 18:49 WIB (diunduh 29/02/2012, 12:45) 